ンが活発に行われている.

研究的側面に加えて, レスキュー関係の研究の重要性や必要 性を広く社会にアピールする啓発活動も, 継続的に進められて いる. 具体的には，毎年開催される「RoboCup Rescue $\rfloor^{(4)}$ や 「レスキューロボットコンテスト」(5)「レスキューロボットコン テストシーズ」(6)，「創造工房」(7)などがある.「Robo Cup Rescue」は競技会の形式をとっており一種のコンテストのよ うであるが研究結果の実証の場として重要な役割を果たしてい る. 2006 年 6 月にはドイッで世界大会が開催され世界中からの 研究者が集まってきた。それに対して「レスキューロボットコ ンテスト」は将来レスキューロボット研究に携わってくれる高 校生や高専生, 大学生などの若者を発掘するという役割があ る.こちらは 2006 年 8 月に神戸で第 6 回競技会が開催される. さらに「レスキューロボットコンテストシーズ」は小学生や中 学生などをターゲットにこの分野の有用性を訴えることを目指 している.ここ数年, 広島や長岡では大規模に実施されてきて いる。また「創造工房」はIRS と神奈川県とが合同で開催する レスキューロボットを題材にしたロボット教室である.

このようにここ数年で, 小学生から研究者までのシームレス な社会啓発活動と研究活動を支えるさまざまな動きが出そろっ てきている. 近い将来これらの活動が有機的に連携するものと 思われるが，そうなったとき災害対応技術は非常に大きく飛躍 すると思われる。

阪神淡路大震災以降も日本ではしばしば大きな被害を伴った 地震が発生している。 また今からの 30 年間に南海・東南海・ 東海地震, 宮城県沖地震などが発生する確率は非常に高くなっ てきている。レスキューシステムの開発は常に現在の技術で構 築可能なシステムを確実に実現してゆくという姿勢が重要であ る。このことは毎年思い出して研究開発・啓発活動を進めて行 かねばならない.

[大須賀公一 神巨大学]

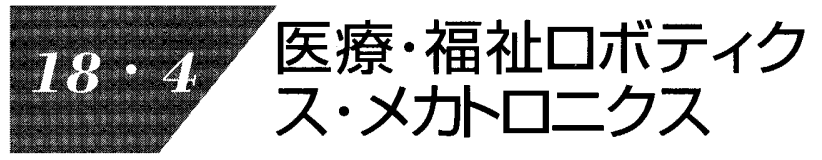

医療用ロボティクス・メカトロニクスの研究は, ICRA, IROS, JSME (ロボティクス・メカトロニクス部門, 情報・効 能・精密機器部門ほか), ロボット学会など工学系学会の中で セッションとして組まれたものと, MICCAI (Medical Image Computing and Computer Assisted Intervention), CARS (Computer Assisted Radiology \& Surgery), コンピュータ外科 学会などの医工連携・共催学会に括いて多くの演題を集めてい る.また, IEEEとSICEの合同開催の国際会議The First International Conference on Complex Medical EngineeringCME 2005 や，2006 年 2 月にイタリアにて開催される Bio Rob 2006 など，新しく開催する国際会議の出現も見られ，これら は医工連携分野のますますの裾野の広がりを示している.

研究トピックスについて, キーワードによる研究動向として は, 2004 年に引き続き整形外科用のロボットの話題の多さ, 胎児治療などの新医療分野への展開の深まりが挙げられるが, 大きな動向の変化が起きてはいない.また, 従来診断用であっ た MRI をロボットと組むことにより治療に用いる動きは数年 来開発されているが，2005年は基礎的な研究に加え，MRI 対応 性（高磁場環境）を備えた, より高度な作業・動作を行う口 ボット・画像誘導治療システムを目指した研究が多く見られる
ようになった。

医療ロボティクスの産業への展開・普及・市場への拡大の キーとなるのが, 開発したロボット・システムの評価である が, 評価のためには臨床での使用が不可欠となる。しかし, 現 在の薬事法による規制下においては，薬事と同等の開発体制・ 治験プロセスを経なければ承認・保険収載への道が開かれない 高いハードルがある。これは, 医療機器の有用性・安全性を評 価し, 議論する体系が十分にとられていないことが一因であ り，これをうけて研究者・行政・医療機関で共通の評価指標を 持たせ，事業化を迅速に行うための指標（ガイドライン）作り が 2003 年よりスタートした。具体的には, 経済産業省・厚生 労働省による「医療機器開発ガイドライン作成事業」が 2005 年から本格的に動きだした.医療ロボティクスを含めた先端的 な医療機器の開発産業の活発化が今後期待できる ${ }^{(8)}$.

福祉ロボティクス・メカトロニクスの研究も医療と同様にし て, 工学系学会のほか, ライフサポート学会, 日本生活支援工 学会などの, 医師, 現場で働く PT (理学療法士), OT (作業 療法士）らの意見が得られる学会などで演題を集めている. 動 向としては，アクチュエータ・制御技術の進歩により，よりコ ンパクトかつ高出力の機械が実現でき始めていることから, 市 場性もあるテーマである上肢・下肢のリハビリテーション, 歩 行訓練・作業支援する身体装着タイプのパワーアシスト装置の 研究開発が目立つ。さらに, それらの機器に自律性を持たせ た, 知能化システムの研究なども研究され始めている.また, 高齢者との会話をし, かつ在宅モニタリングする癒し系パーソ ナルロボットの販売や, 食事支援ロボットの販売の海外進出な どの動きがあり, 積極的な市場への展開がなされ始めていると いえる。

最後に, 2005 年は愛知万博が開催され, 医療系のロボティ クスでは遠隔微細手術ロボットや救命支援ロボットなど, 最先 端技術の紹介が多くなされ，また福祉系では垁用化ロボットと して自律走行機能を持つ車いすの垁証実験や, チャイルドケア ロボット, ロボットスーツなど, 幅広い応用機器が実際に動 き, ロボティクス分野拈よび, 医療・福祉ロボティクスの研究 の活況さを印象付けた ${ }^{(9)}$.

\section{〔正宗〔賢 東京大学〕}

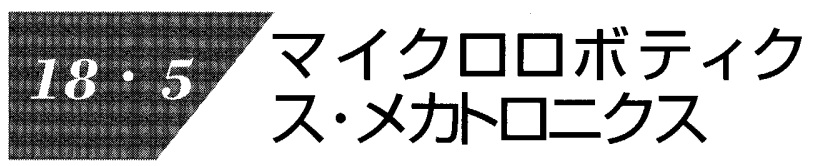

2005 年に国内外で開催された会議の中から関連するトピッ クスを挙げながら，本分野のトレンドを概観する。

本分野はロボティクス・メカトロニクスと MEMS の融合領 域でもあるが, ここ数年の MEMS 研究の傾向としてバイオ応 用を目指した研究が盛んに行われるようになっており, IEEE MEMS 2005 や IEEE Transducers' 05 を見てもバイオ関連研究 の発表件数が非常に多い. その多くは微小空間に打ける生化学 反応計測や微小流体制御などに注目したものである。その中で も, 機械的な可動部を有するマイクロポンプやマイクロバルブ の研究は, 本分野がバイオ応用で貢献する重要なメカト口技術 の一つである. また, 損傷した神経細胞の軸索を切断, マニ ピュレーション, 接合する微小な手術ツールや, 集束イオン ビームによる化学気相成長法を用いた細胞手術用の 3 次元ナノ ッール, 単一細胞の電気計測用ナノ電極などの微小な機械要素 は，本分野との連携により今後大きく成長するものと期待でき 